\title{
Positive Effect of Plant-Based Diet on the Performance and Health of Laying Hens
}

\author{
E. STRAKOVÁ, P. SUCHÝ, M. ŠUGERKOVÁ, M. MACHÁČEK
}

Department of Nutrition, Animal Husbandry and Animal Hygiene, Faculty of Veterinary Hygiene and Ecology, University of Veterinary and Pharmaceutical Sciences Brno, Czech Republic

Received April 25, 2007

Accepted October 2, 2007

\begin{abstract}
Straková E., P. Suchý, M. Šugerková, M. Macháček: Positive Effect of Plant-Based Diet on the Performance and Health of Laying Hens. Acta Vet. Brno 2007, 76: S31-S37.

An entirely plant-based feed mixture was prepared to minimize the potential risk of transmitting prion infections through animal feed. It consisted of two protein components (soya extracted meal and lupin seed meal) and was compared with a diet containing animal protein components (fish meal). The objective of the present work was to prepare and verify the effect of the entirely plant-based diet on the performance, selected qualitative indicators of eggs and the hens' state of health. A specially prepared feed mixture containing fish meal was used as a control diet. The tested plant-based diet administered to experimental hens produced no negative effect on egg production variables such as number of eggs per hen or laying performance. The weight of eggs laid by experimental hens was significantly higher $(61.66 \mathrm{~g}, P \leq 0.01)$, as compared with the control group $(60.03 \mathrm{~g})$. The higher average weight of eggs in the experimental group increased the production of egg mass per layer by $540 \mathrm{~g}$ in 252 -day experimental period. The beneficial effect of the plant-based diet was demonstrated particularly in the improved egg quality, manifesting itself in a highly significant improvement in yolk colour $(P \leq 0.01)$ and a significant decrease $(P \leq 0.05)$ in cholesterol level in egg yolk. Haematological examination did not indicate statistical differences between experimental and control layers in red blood cell indices such as RBC, haemoglobin, hematocrit, $\mathrm{MCHC}, \mathrm{MCH}$, and $\mathrm{MCV}$, while white blood cell indices showed a highly significant increase $(P \leq 0.01)$ in Le in experimental hens. Biochemical tests performed in blood plasma revealed significantly lower molar concentrations of glucose $(P \leq 0.05)$ and highly significantly lower levels of total lipids, cholesterol, lipoproteins (HDL and LDL) in experimental hens $(P \leq 0.01)$, as compared with the control group. The results of the study confirm that animal protein in diet for laying hens can be replaced by combination of vegetable protein feeds (soybean and lupin protein) without a negative impact on their performance and health, thereby contributing to solving issues of food safety (a prevention of prion infections).
\end{abstract}

Hens, nutrition, egg production, egg quality, haematological and biochemical examination of blood

In terms of the safety and quality of raw materials and foodstuffs originating from animals, constant effort in the area of animal nutrition goes into preventing the contamination of feeds with substances that may put human health at risk. The replacement of animal feed with plant-based feed may offer a potentially useful solution to this problem. Due to bovine spongiform encephalopathy in ruminants, a new strategy in the nutrition of animals reared for the production of feed was elaborated. First papers pointing out the option of preparing entirely plant-based diets were published by Suchý et al. (2002) although meat-and-bone meals were an integral part of feed mixtures for poultry (particularly laying hens) at that time. The effect of the diets administered to hens used for production of consumer eggs should be assessed in respect to both egg production performance and egg quality. In this respect, the composition of the egg (i.e. egg shell, egg white and egg yolk) is considered to be the basic indicator to be evaluated, together with the level of egg cholesterol, which reflects consumer health aspects, and egg yolk colour, which characterises egg attractiveness to consumers. The effect of the diets with and without animal protein (meat-and-bone meal)

Address for correspondence:

Eva Straková

Department of Nutrition, Animal Husbandry and Animal Hygiene

University of Veterinary and Pharmaceutical Sciences

Palackého 1-3

61242 Brno, Czech Republic

Phone: +420541562672

Fax: +420541562 675

E-mail: strakovae@vfu.cz

http://www.vfu.cz/acta-vet/actavet.htm 
was studied by Angelovičová and Michalík (1993) and Tůmová et al. (2004). Egg colour is an important indicator that makes an egg attractive for consumers. This issue including the objective methods of colour determination was addressed by Dvořák et al. (2001, 2003, 2004). Dvořák et al. (2005) confirmed the improvement of yolk colour after the addition of plant-based components containing natural plant pigments into the feed mixtures. From the consumer health point of view, the level of cholesterol in egg yolk is of a great importance. The quality of eggs including the evaluation of cholesterol levels in egg yolk was studied by Tủmová et al. (2004), Wang and Pan (2003) and Murata et al. (2003). There are only a few scientific papers on the metabolic profile of clinically healthy hens during a laying period, which is one of the major indicators of the hens' state of health. Papers by Kirchgessner et al. (1996), Suchý et al. (2001) and Straková et al. (2001) represent fundamental work in this area.

In our work we have suggested a hypothesis to prove that a suitable combination of plant-based diets can fully replace both fish meal and also any protein originating from animals in a diet for laying hens without producing any negative effects such as decreased production performance of feed mixtures, decrease in egg quality or negative impact on the hens' state of health.

\section{Materials and Methods}

A total of 72 laying hens of the ISA Brown hybrid combination at the age of 22 weeks were randomly assigned to the control $(n=36)$ and experimental $(n=36)$ group. The hens were reared individually in cages in an accredited enclosure at the Department of Nutrition, Animal Husbandry and Animal Hygiene, University of Veterinary and Pharmaceutical Sciences Brno at the temperature of $18{ }^{\circ} \mathrm{C}$ and 16-hour photoperiod. Layers were fed ad libitum by manual feeding. Watering took place by nipple automatic drinkers. The experimental period lasted 252 days (from 22 to 58 weeks of hen age).

During the experiment, layers were fed commercial complete feed mixtures N1 (from 22 to 40 weeks of age; the first part of laying period) and N2 (from 41 to 58 weeks of age; the second part of laying period). The control group received feed mixture in which fish meal and soya extracted meal were the sources of protein. Soya extracted meal and meal from seeds of yellow lupin (Lupinus luteus variety Juno) in amounts of 10\% (N1) and 6\% (N2) were used as the vegetable protein sources in the experimental group. Both the experimental and the control feed mixtures were comparable in respect to energy content and nutrient composition (Table 1).

In the course of the experimental period, both the number and weight of laid eggs were monitored daily. During the laying period, eggs were also examined for the presence of defects such as defective egg shell (membranous or cracked egg). The data obtained were used to evaluate the average weight of eggs, the number of laid eggs per laying hen, laying performance, the production of egg mass per laying hen and the portion of eggs with a defective egg shell per laying period (as a percentage).

Eggs from each laying hen in both groups were collected at 28-day intervals during the experiment in order to determine selected qualitative indicators: egg weight, egg shell weight, weight of white and yolk by weighing at a precision of $0.01 \mathrm{~g}$. The corresponding data were used to calculate the relative portion of the egg shell, egg white, and egg yolk per egg. The colour of egg yolk was assessed using the standard Hoffman-La Roche yolk colour scale and the level of cholesterol was determined photometrically using the commercially available BIOLA-TEST kits (Pliva Lachema a.s., Czech Republic).

Haematological and biochemical tests of blood samples obtained by puncture of the vena basilica in 10 hens from each group, were performed at 28-day intervals. Collected blood samples were stabilized with heparin. The following haematological indicators were determined: red blood cell count (RBC), white blood cell count (WBC), haemoglobin content and haematocrit value. These values were used to calculate following red blood cell indices: the mean corpuscular haemoglobin concentration (MCHC), mean corpuscular haemoglobin (MCH), and mean corpuscular volume (MCV). Haematological values were determined using classical haematological methods according to Doubek (2003). The following biochemical indicators were determined in blood plasma: the molar concentrations of total protein, glucose, total lipids, cholesterol, lipoproteins (HDL and LDL), Ca, P, and Mg. The biochemical examination of blood plasma was performed using the Cobas Mira automatic analyser (Roche Diagnostic Systems, Switzerland).

The data obtained were evaluated using the statistical programme STAT PLUS.

\section{Results}

Table 2 shows that the plant-based diet did not substantially affect the performance characteristics of hens such as the number of laid eggs per laying hen and the laying 
Table 1. Nutrient composition of complete feed mixtures containing animal protein (control groups) and vegetable protein (experimental groups)

\begin{tabular}{|c|c|c|c|c|}
\hline $\begin{array}{l}\text { Nutrients } \\
\text { (g/kg if not specified } \\
\text { otherwise) }\end{array}$ & $\begin{array}{l}\text { Control group } \\
\qquad \mathrm{N} 1^{1}\end{array}$ & $\begin{array}{l}\text { Experimental group } \\
\text { N1 }\end{array}$ & $\begin{array}{l}\text { Control group } \\
\mathrm{N} 2^{2}\end{array}$ & $\begin{array}{c}\text { Experimental group } \\
\text { N2 }\end{array}$ \\
\hline Dry matter & 895.0 & 899.3 & 892.6 & 894.0 \\
\hline Crude protein & 185.0 & 185.0 & 162.8 & 161.5 \\
\hline Lysine & 8.6 & 8.5 & 7.5 & 7.5 \\
\hline Methionine & 4.3 & 4.3 & 3.8 & 3.7 \\
\hline Threonine & 6.2 & 6.2 & 5.5 & 5.6 \\
\hline Tryptophan & 1.8 & 1.8 & 1.7 & 3.8 \\
\hline Arginine & 11.0 & 13.1 & 9.4 & 10.6 \\
\hline Isoleucine & 6.6 & 6.8 & 5.7 & 5.8 \\
\hline Fat & 34.1 & 56.6 & 30.6 & 39.7 \\
\hline Fibre & 27.2 & 35.3 & 30.1 & 31.5 \\
\hline Nitrogen free extract & 536.0 & 493.5 & 554.4 & 538.8 \\
\hline Starch & 412.6 & 345.5 & 441.6 & 420.1 \\
\hline $\begin{array}{l}\text { Metabolisable energy } \\
(\mathrm{MJ} / \mathrm{kg})\end{array}$ & 11.7 & 11.7 & 11.3 & 11.3 \\
\hline Ash & 115.6 & 124.1 & 114.3 & 119.3 \\
\hline Calcium & 36.0 & 36.0 & 35.3 & 35.3 \\
\hline Phosphorus & 7.7 & 7.2 & 6.3 & 6.3 \\
\hline Magnesium & 2.3 & 1.6 & 2.1 & 1.5 \\
\hline
\end{tabular}

${ }^{1}-\mathrm{N} 1$ : admistered to hens from 22 to 40 weeks of age.

${ }^{2}-\mathrm{N} 2$ : admistered to hens from 41 to 58 weeks of age.

performance. Hens fed the plant-based diet produced more egg mass as a result of significantly higher $(P \leq 0.01)$ average weight of eggs $(61.66 \mathrm{~g})$ as compared with the control $(60.03 \mathrm{~g})$. The quality of the egg shell remained unchanged, as evaluated on the basis of percentage of eggs with a defective egg shell per laying period (Table 2).

The analysis of 324 eggs collected from both the experimental and the control group during the experiment showed that the weight of the egg shell and the egg white in the experimental group increased $(P \leq 0.01)$ by $0.31 \mathrm{~g}$ and $0.98 \mathrm{~g}$, respectively. There were no statistically significant differences in average values for yolk between the groups. When the individual parts of the egg were expressed in percentages, the portion of the egg shell increased by $0.24 \%$ in the experimental group as compared with the control $(P \leq 0.01)$. The opposite trend was found for the egg yolk, as its average value in the eggs from experimental layers decreased by $0.57 \%$ as compared with the control $(P \leq 0.01)$. The relative portion of the egg white was the same in both groups. Egg yolks of the experimental group showed significantly darker colour $(P \leq 0.01)$ and had significantly lower $(P \leq 0.05)$ cholesterol level (Table 2).

Ninety blood samples were collected and analysed from each group during the experiment. As documented in Table 3, the haematological examination did not show statistically significant differences between the groups of hens in the average values of the indicators observed, except for the white blood cell count, which was significantly higher $(P \leq 0.01)$ in experimental hens $(15.70 \mathrm{G} / 1)$, as compared with the control $(13.98$ $\mathrm{G} / \mathrm{l})$. Some differences were found between the groups in the biochemical examination of blood plasma. Experimental laying hens showed significantly lower $(P \leq 0.05)$ molar concentrations of glucose $(12.403 \mathrm{mmol} / \mathrm{l})$ and significantly lower $(P \leq 0.01)$ concentrations of triglycerides (14.317 mmol/l), cholesterol (4.319 mmol/l), and HDL (1.898 mmol/l) and 
Table 2. The results of the evaluation of performance and egg quality in the laying hens fed on a diet consisting of animal protein (control group) and with an entirely plant-based mixture (experimental group)

\begin{tabular}{|l|c|c|}
\hline Egg indicators & Control group & Experimental group \\
\hline Performance indicators & 7583 & 7543 \\
\hline Total number of laid eggs & 218 & 221 \\
\hline E/1H & 13087 & 13627 \\
\hline PEM & 86.51 & 86.11 \\
\hline Laying performance (\%) & $60.03 \pm 5.308^{* *}$ & $61.66 \pm$ \\
\hline Weight of eggs (g) & 2.77 & 2.96 \\
\hline Cracked eggs (\%) & 0.41 \\
\hline Membranous eggs (\%) & 0.16 & $7.48 \pm$ \\
\hline Qualitative parameters & $7.17 \pm 0.684^{* *}$ & $0.748^{* *}$ \\
\hline Weight of egg shell (g) & $36.33 \pm 3.638^{* *}$ & $37.31 \pm$ \\
\hline Weight of white (g) & $15.96 \pm 1.597$ & $15.96 \pm$ \\
\hline Weight of yolk (g) & $12.07 \pm 0.880^{* * *}$ & 1.771 \\
\hline Weight of egg shell (\%) & $61.16 \pm 2.558$ & $12.31 \pm$ \\
\hline Weight of white (\%) & $26.76 \pm 2.360^{* *}$ & $26.958^{* *}$ \\
\hline Weight of yolk (\%) & $5.87 \pm 0.681^{* *}$ & $6.44 \pm$ \\
\hline Yolk colour & $1131.94 \pm 92.305^{*}$ & $2.736^{* *}$ \\
\hline Yolk cholesterol (mg/100 g) & & $1116.09 \pm 100.399^{* *}$ \\
\hline
\end{tabular}

Means \pm standard deviation.

${ }^{*}, * *$ - the values within the same row differ significantly $(P \leq 0.05$ and $P \leq 0.01$, respectively).

$\mathrm{E} / 1 \mathrm{H}$ : the mean number of laid eggs per hen in 28 days, $\mathrm{PEM}$ : the mean production of egg mass during the experiment.

LDL (1.324 mmol/l) lipoproteins (Table 3). No statistically significant differences between the groups of layers were found in the plasma levels of $\mathrm{Ca}, \mathrm{P}$ and $\mathrm{Mg}$.

\section{Discussion}

The results obtained in this experiment have shown that diets only consisting purely of plant components can be formulated for the feeding of laying hens without there being any negative impact on their production performance. The production of egg mass increased by $540 \mathrm{~g}$ per layer during the 252-day experimental period. This increase in the production of egg mass is associated with a very significant increase $(P \leq 0.01)$ in the average weight of eggs in hens of the experimental group.

The positive effect of the plant-based diet was particularly reflected in some of the egg quality indicators; namely in the increase in egg shell weight (both absolutely and relatively), which is one of the major factors that affects positively the thickness and strength of the egg shell. It follows from the results that the increase in egg weight in the experimental group is also associated with a very significant increase $(P \leq 0.01)$ in the weight of the egg white, while the weight of egg yolk remained practically unchanged as compared with the control group. Consequently, the relative portion of the yolk in control eggs was significantly higher $(P \leq 0.01)$ than that of the experimental. The egg weight, including the relative ratio of all the egg shells, whites and yolks determined in both groups, showed typical variability reported by Angelovičová and Michalík (1993) and Tůmová et al. (2004) for hen eggs.

With regard to the attractiveness of eggs in respect to consumer demands, the colour of egg yolk in the experimental group changed significantly, being of a darker shade $(P \leq$ $0.01)$. The enhanced colour of egg yolk is probably associated with the increased level of plant pigments in the plant-based diet containing the Juno yellow variety of lupin. Similar findings were also reported by Dvořák et al. (2005). 
Table 3. The results of the evaluation of the haematological and biochemical examination of blood in the laying hens fed on a diet consisting of animal protein (control group) and with an entirely plant-based mixture (experimental group)

\begin{tabular}{|l|r|r|}
\hline Blood indicators & Control group & Experimental group \\
\hline Haematological indicators & $2.212 \pm 0.363$ & $2.152 \pm 0.321$ \\
\hline RBC (T/l) & $71.527 \pm 7.522$ & $71.871 \pm 6.581$ \\
\hline Haemoglobin (g/l) & $0.282 \pm 0.026$ & $0.283 \pm 0.025$ \\
\hline Hematocrit (1/1) & $25.253 \pm 1.917$ & $25.421 \pm 1.406$ \\
\hline MCHC (\%) & $33.989 \pm 5.600$ & $34.733 \pm 5.442$ \\
\hline MCH (pg) & $133.962 \pm 21.978$ & $136.962 \pm 22.903$ \\
\hline MCV (fl) & $13.980 \pm 2.869^{* *}$ & $15.700 \pm 3.948^{* *}$ \\
\hline WBC (G/l) & & \\
\hline Biochemical plasma indicators & $49.670 \pm 3.176$ & $49.447 \pm 3.310$ \\
\hline Total protein (g/l) & $12.698 \pm 0.798^{*}$ & $12.403 \pm 0.831^{*}$ \\
\hline Glucose (mmol/l) & $15.187 \pm 1.858^{* *}$ & $14.317 \pm 1.910^{* *}$ \\
\hline Total lipids (g/l) & $4.565 \pm 0.624^{* *}$ & $4.319 \pm 0.456^{* *}$ \\
\hline Cholesterol (mmol/l) & $2.037 \pm 0.322^{* *}$ & $1.896 \pm 0.262^{* *}$ \\
\hline HDL (mmol/l) & $1.474 \pm 0.244^{* *}$ & $1.324 \pm 0.211^{* * *}$ \\
\hline LDL (mmol/l) & $6.561 \pm 0.399$ & $6.708 \pm 0.688$ \\
\hline Calcium (mmol/l) & $1.849 \pm 0.426$ & $1.907 \pm 0.161$ \\
\hline Phosphorus (mmol/l) & $0.813 \pm 0.042$ & $0.814 \pm 0.038$ \\
\hline Magnesium (mmol/l) & & \\
\hline
\end{tabular}

Means \pm standard deviation.

${ }^{*}{ }^{* *}$ - the values within the same row differ significantly $(P \leq 0.05$ and $P \leq 0.01$, respectively).

RBC: total red blood cells, MCHC: Mean Corpuscular Haemoglobin Concentration, MCH: Mean Corpuscular Haemoglobin, MCV: Mean Corpuscular Volume, WBC: Total White Blood Cells, HDL: High-Density Lipoprotein, LDL: Low-Density Lipoprotein

One very positive effect of the plant-based diet with regard to the nutritional value of eggs is that it significantly decreased $(P \leq 0.05)$ the cholesterol level in egg yolk in experimental hens. This effect is assumed to be associated with the absence of animal component in the plant-based diet. The results obtained also correspond with those published by Tůmová et al. (2004) and Murata et al. (2003).

The hens' state of health can be assessed objectively on the basis of regular haematological and biochemical tests on blood samples collected from hens.

The results of haematological tests showed that the plant-based diet had no negative effect on the studied haematological indicators. This statement is supported by the fact that red blood cell indices in the experimental group did not differ from those in the control group during the whole experiment. Red blood cell indices are in accordance with the results of haematological tests in clinically healthy hens reported by Straková et al. (2001).

It follows from the haematological tests that both groups differed significantly $(P \leq 0.01)$ in the total leukocyte count that increased in experimental laying hens. This is a positive finding as it indicates enhanced leucopoiesis in experimental laying hens.

Biochemical tests on samples of hen blood plasma showed a significantly lower level of glucose in the experimental group $(P \leq 0.05)$. We suppose that one of the reasons for a decrease in the molar concentration of plasma glucose is that the level of production in laying hens increased as a result of the increasing energy demand due to the increasing weight of eggs and the connected enhanced production of egg mass.

A highly significant decrease $(P \leq 0.01)$ in the levels of plasma lipids, cholesterol, and lipoproteins (HDL and LDL) is another positive effect of the plant-based diet on 
the metabolic profile of experimental hens. It can be assumed that the highly significant decrease in the parameters of lipid metabolism is associated with the decreased cholesterol levels in egg yolk in the experimental group. The plasma level of protein is one of the indicators that did not differ statistically between groups. We therefore failed to prove the finding reported by Kirchgessner et al. (1996) that the addition of lupin to a diet decreased the plasma level of protein in hens.

The molar concentrations of bone-forming elements in blood plasma (Ca, P, Mg) did not significantly vary between the two groups. This proves that the plant-based diet tested had no negative effect on the metabolism of these minerals in experimental hens.

Despite the differences between the groups in the monitored biochemical indicators, it can generally be concluded that these variables ranged within normal physiological limits and that they are in accordance with biochemical studies conducted on clinically healthy hens by Suchý et al. (2001).

In conclusion, it follows from the results obtained that suitably designed diets for feeding laying hens may fully replace diets consisting of animal components, without producing negative effects on the production performance of hens or the hens' state of health. Any suitable plant-based diet can increase the quality of eggs as well as the attractiveness of eggs for consumers, maintaining good state of health of laying hens and improving the safety of this significant foodstuff.

\section{Pozitivní vliv vegetabilní diety na produkci a zdravotní stav užitkových nosnic}

V souvislosti s potencionálním rizikem přenosu prionových infekcí krmivy animální provenience byla za použití kombinace dvou vegetabilních proteinových krmiv (sojový extrahovaný šrot a šrot z lupinových semen) připravena čistě vegetabilní krmná směs a bylo provedeno její porovnání s dietou s obsahem animální proteinové komponenty rybí moučky. Cílem práce bylo připravit a ověřit vliv čistě vegetabilní diety na produkci, vybrané kvalitativní ukazatele vajec a zdravotní stav nosnic. Jako kontrolní dieta byla použita speciálně připravená krmná směs s rybí moučkou. Testovaná vegetabilní dieta, podávaná pokusné skupině slepic negativně neovlivnila produkci vajec ve vztahu $\mathrm{k}$ počtu snesených vajec na 1 slepici a intenzitu snášky. Slepice pokusné skupiny snášely vysoce průkazně $(P \leq 0,01)$ těžší vejce 61,66 g oproti kontrolním slepicím $60,03 \mathrm{~g}$. Vyšší průměrná hmotnost vajec u pokusné skupiny zvýšila za 252 dnů experimentu produkci vaječné hmoty na 1 slepici o 540 g. Pozitivní vliv vegetabilní diety spatřujeme především ve zlepšení kvality vajec, manifestující se vysoce průkazným $(P \leq 0,01)$ zlepšením barvy žloutku a průkazným $(P \leq 0,05)$ poklesem cholesterolu ve vaječném žloutku. Při hematologickém vyšetření pokusné a kontrolní skupiny slepice nevykazovaly rozdíly u sledovaných ukazatelů červeného krevního obrazu (Er, Hb, Hk, MCHC, MCH a MCV). U bílého krevního obrazu bylo zaznamenáno vysoce průkazné $(P \leq 0,01)$ zvýšení Le u pokusných slepic. Při biochemickém vyšetření krevní plazmy slepice pokusné skupiny vykazovaly nižší molární koncentrace u glukózy průkazně $(P \leq 0,05)$, u celkových lipidů, cholesterolu, lipoproteidu HDL a LDL vysoce průkazně $(P \leq 0,01)$ ve srovnání s kontrolou. Výsledky práce potvrzují, že lze nahradit animální protein v dietě pro nosnice užitkové kombinací vegetabilních proteinových krmiv (sojový a lupinový protein) bez negativního dopadu na jejich užitkovost a zdravotní stav, a tím přispět k řešení otázek spojených $\mathrm{s}$ bezpečností potravin (prevence prionových nákaz).

\section{Acknowledgement}

This research was conducted within the Research Plan of the Czech Republic Ministry of Education, Youth, and Physical Training No. MSM6215712402 "Veterinary Aspects of Food Safety and Quality". 


\section{References}

ANGELOVIČOVÁ M, MICHALÍK I 1993: The effect of chemical treatment of maize on utilization of nutrients from feed mixtures for laying hens in relation to egg-production and quality. Živoč Výr 39: 611-624

DOUBEK J 2003: Veterinární hematologie. Noviko, Brno, 464 pp.

DVOŘÁK P, GROLICHOVÁ M, MUSILOVÁ H 2004: Einfluss der ionisierenden Strahlung auf die Farbe und Tropfsaftverlust von Schweinefleisch. Fleischwirtschaft 84: 122-124

DVORÁK P, KUNOVÁ J, STRAKOVÁ E, SUCHÝ P, KUNOVÁ V 2005: Changes in the colour and the acidity number of egg yolk upon irradiation. Eur Food Res Technol 221: 348-350

DVOŘÁK P, MUSILOVÁ H, GROLICHOVÁ M, PÁČ J 2003: A change in meat colour caused by the effect of atmospheric oxygen. Fleischwirtschaft Int 2: 50-54

DVOŘ́K P, MUSILOVÁ H, ŠVARCOVÁ I 2001: On-line measurements of colour of pork. Fleischwirtschaft 81: $89-91$

KIRCHGESSNER M, EDER K, ROTH-MAIER DA 1996: The effect of enzyme supplements and white lupins (Lupinus albus L.) on concentrations of lipids in serum and eggs of layers. Arch Geflügelkd 60: 109-113

MURATA LS, ARIKI J, MACHADO CR, SILVA LPG, REZENDE MJM 2003: Effect of oils sources on blood lipid parameters of commercial laying hens. Rev Bras Cienc Avic 5: 203-206

STRAKOVÁ E, VEČEREK V, SUCHÝ P, KŘESALA P 2001: Red and white blood-cell analysis in hens during the laying period. Czech J Anim Sci 46: 388-392

SUCHÝ P, STRAKOVÁ E, VEČEREK V, SLEZÁČKOVÁ I 2002: Replacement of animal origin feed by plant origin feed in the diet of broiler chickens. Czech J Anim Sci 47: 365-3731

SUCHÝ P, STRAKOVÁ E, VEČEREK V, ŠTERC P 2001: Biochemical studies of blood in hens during the laying period. Czech J Anim Sci 46: 383-387

TŮMOVÁ E, HÄRTLOVÁ H, LEDVINKA Z, FUČÍKOVÁ A 2004: The effect of digitonin on egg quality, cholesterol content in eggs, biochemical and haematological parameters in laying hens. Czech J Anim Sci 49: 33-37

WANG JJ, PAN TM 2003: Effect of red mold rice supplements on serum end egg yolk cholesterol levels of laying hens. J Agric Food Chem 51: 4824-4829 